CENDEKIA UTAMA

Jurnal Keperawatan dan

Kesehatan Masyarakat

STIKES Cendekia Utama Kudus
P-ISSN 2252-8865

E-ISSN 2598-4217

Vol. 9, No. 2 - Oktober, 2020

Tersedia Online:

htpp://jurnal.stikescendekiautamakudus.ac.id

\title{
TINGKAT KEPUASAN PEMASANGAN DAN KENDALA PEMAKAIAN PENGGUNA KB IUD PASCA SALIN
}

\author{
Devi Permata Sari ${ }^{1}$, Ivanna Beru Brahmana ${ }^{2}$, Inayati ${ }^{3}$, Ana Majdwati ${ }^{4}$ \\ ${ }^{1}$ Stikes Muhamamdiyah Klaten, ${ }^{2,3,4}$ Universitas Muhammadiyah Yogyakarta \\ Email: devisari_07@yahoo.com
}

\begin{abstract}
ABSTRAK
Intra Uterine Device (IUD) merupakan alat kontrasepsi dalam rahim yang waktu pemasangannya bisa dilakukan paska persalinan dan interval. Intra Uterine Device paska persalinan (IUDPP) merupakan metode pemasangan atau insersi IUD segera setelah plasenta lahir, yang biasanya dilakukan 10 menit paska pelepasan plasenta. Tujuan penelitian adalah mengetahui tingkat kepuasan pemasangan dan kendala pemakaian pengguna KB IUD Pasca Salin. Penelitian ini menggunakan design observasional analitik, pendekatan cross sectional study dari data rekam medis pasien di RSIA 'Aisyiyah Klaten yang mendapat IUDPP. Sampel yang digunakan adalah 82 presponden. Hasil Penelitian menunjukkan. kendala penggunaan KB IUD PP mayoritas adalah pada haid tidak teratur yaitu sejumlah 44 responden (53.6\%). Sedangkan untuk kendala seksual dan nyeri kepala, kelamahan merupakan kendala minoritas pada responden pengguna KB IUD PP yaitu sejumlah 5 responden (6.1\%). kepuasan pemasangan KB IUD PP mayoritas adalah pada menandatangai inform consent tanpa paksaan yaitu sejumlah 82 responden (100\%). Sedangkan mayoritas responden mearasa tdak puas pada aspek aman dan nyaman selama pemasangan responden pengguna $\mathrm{KB}$ IUD PP yaitu sejumlah 17 responden $(20.8 \%)$.
\end{abstract}

Kata Kunci: IUDPP, Tingkat Kepuasan, Kendala Pemasangan IUDPP

\section{ABSTRACT}

Intra Uterine Device (IUD) is a contraceptive device in the uterus that can be inserted after delivery and at intervals. Postpartum Intra Uterine Device (IUDPP) is a method of inserting or inserting an IUD immediately after delivery of the placenta, which is usually done 10 minutes after removal of the placenta. The research objective was to determine the satisfaction level of the installation and the constraints in using post-copy family planning IUD users. This study used an analytical observational design, cross sectional study approach from medical records of patients at RSIA 'Aisyiyah Klaten who received IUDPP. The sample used was 82 respondents. The results showed. The majority of the constraints in using the IUD PP FP were on irregular menstruation, namely 44 respondents (53.6\%). Meanwhile, for sexual constraints and headaches, weakness is a minority constraint among respondents who use the IUD PP KB, namely 5 respondents (6.1\%). The majority of the satisfaction with the placement of the IUD PP I installation was in signing informed consent without coercion, namely 82 respondents $(100 \%)$. 
While the majority of respondents felt dissatisfied with the safe and comfortable aspects during the installation of the PP IUD users, 17 respondents (20.8\%).

Keywords: IUD after birth, Satisfaction Level, Constraints on IUD Afterbirt insertion

\section{LATAR BELAKANG}

Angka Kematian Ibu (AKI) di Indonesia menurut Survei Demografi dan Kesehatan Indonesia (SKDI) tahun 2012 sebesar 359 per 100.000 kelahiran hidup. Angka tersebut masih termasuk tinggi, oleh karena target global Millenium Development Goals (MDGs) yang ke-5 adalah menurunkan AKI menjadi 102 per 100.000 kelahiran hidup pada tahun 2015. Upaya yang dilakukan sehubungan dnegan hal tersebut adalah mencegah kehamilan dengan cara turut berpartisipasi sebagai akseptor KB. Wanita Usia Subur (WUS) yang bukan akseptor KB ada tahun 2013 sebesar 38\%. Mereka lebih berpeluang mengalami kehamilan dan berisiko meninggal ketika melahirkan (Brahmana, 2018).

Intra Uterine Device (IUD) atau dikenal dengan KB spiral merupakan metode KB jangka panjang, yang bisa dipakai selama 5, 8, atau 10 tahun. Pemasangan IUD biasanya dilakukan pada masa interval, yakni setelah selesai masa nifas (sekitar 40 hari setelah melahirkan) atau setelahnya. Dengan cara ini, kemungkinan ibu tidak datang kontrol saat setelah nifas atau sesudahnya, memungkinkan ibu tidak ber-KB akan lebih besar. Dengan demikian ibu mempunyai peluang untuk hamil lagi akan lebih besar. Untuk itu disosialisasikan pemasangan $\mathrm{KB}$ paska persalinan. Untuk pilihan $\mathrm{KB}$ IUD, maka IUD akan dipasang segera setelah persalinan, yakni sekitar 10 menit paska pelepasan plasenta. Pemasangan IUD Paska Persalinan (IUDPP) bisa dilakukan untuk persalinan pervaginam maupun saat sectio caesarea (SC). Ibu bersalin keluar dari rumah sakit sudah ber-KB sebagai upaya penjarangan kehamilan berikutnya.

Pemasangan IUD Paska Persalinan (IUDPP) diperkenalkan di RSIA 'Aisyiyah, Klaten, Jawa Tengah pada tahun 2015 sebagai Program KB Pilihanku (My Choice) melalui Jhons Hopkins Program Information Education Gynecology and Obstetric (JHPIEGO) dan Bill and Melinda Gates Foundation (BMGF). Kegiatan berupa: ceramah/seminar dan pelatihan pemasangan IUDPP. Kegiatan konseling untuk memberikan informasi tentang KB Paska Persalinan (KBPP) hingga calon akseptor bisa menentukan pilihan jenis KBPP yang dipilih juga dilatihkan oleh JHPIEGO dan BMGF. Selain KBPP, Program KB Pilihanku (My Choice) juga memperkenalkan pemakaian KB Pasca Abortus (KBPA). Sejak dijalankan mulai bulan April 2016 sampai dengan sekarang, kedua program ini tidak mengalami kendala.

Pemasangan IUDPP di RSIA 'Aisyiyah Klaten, Jawa Tengah pada tahun 2016 dan 2017 masing-masing sebesar 83,15\% dan 81,76\%. Pemasangan implant PP sebesar 16,85\% dan 18,24\% untuk tahun 2016 dan 2017 (Brahmana,2018). Pelaksanaan KBPA di RSIA 'Aisyiyah Klaten pada tahun tersebut sebanyak 8\% dari keseluruhan kasus abortus yang dilakukan kuretase, dan $80 \%$ akseptor memilih IUDPA daripada implan PA(Infodatin, 2014)

\section{METODE PENELITIAN}

Metode penelitian yang digunakan dalam penelitian ini adalah observasional analitik dengan pendekatan cross sectional yaitu mendapatkan gambaran tingkat 
kepuasan dan kendala pemasangan pengguna KB IUD. Sampel yang digunakan adalah 82 responden akseptor KB IUD PP

\section{HASIL DAN PEMBAHASAN \\ Analisa Univariat}

Analisa Univariat untuk mengetahui distribusi frekuensi karakteristik responden yang melipuri usia, partus, lama penggunaan $\mathrm{KB}$, kendala pemakaian penggunaan $\mathrm{KB}$ IUDPP,dan tingkat kepuasan pemasangan KB IUD PP. Hasil dari penelitian yang telah dilakukan adalah sebagi berikut:

\section{Data Demografi Responden}

Tabel 1

Rerata Usia Responden (n:82)

\begin{tabular}{lccccc}
\hline \multicolumn{1}{c}{ Variabel } & $\mathrm{N}$ & $\begin{array}{c}\mathrm{Mi} \\
\mathrm{n}\end{array}$ & Max & Mean & SD \\
\hline Usia responden & 82 & 24 & 48 & 33.47 & 5.54 \\
Partus ke & 82 & 1 & 7 & 2.13 & 0.93 \\
Lama penggunaan KB & 82 & 1 & 8 & 3.59 & 1.02 \\
\hline
\end{tabular}

Berdasarkan tabel 1 di atas menunjukkan hasil bahwa rerata usia responden adalah 33,47 tahun dengan $\mathrm{SD} \pm 5,54$. Rerata partus responden adalah 2.13 dengan SD \pm 0.93 . Sedangkan rerata lama penggunaan $\mathrm{KB}$ adalah 3.59 tahun dengan $\mathrm{SD} \pm 1.02$.

\section{Kendala Pemakaian Penggunaan KB IUD Pasca Salin}

Tabel 2

Distribusi Frekuensi Kendala Penggunaan KB IUD Pasca Salin (N :82)

\begin{tabular}{lccccc}
\hline \multirow{2}{*}{$\begin{array}{c}\text { Kendala Penggunaan KB IUD } \\
\text { PP }\end{array}$} & \multicolumn{2}{c}{$\begin{array}{c}\text { Terdapat } \\
\text { Kendala }\end{array}$} & \multicolumn{2}{c}{$\begin{array}{c}\text { Tidak Terdapat } \\
\text { Kendala }\end{array}$} & TOTAL \\
\cline { 2 - 6 } & $\mathrm{f}$ & $\%$ & $\mathrm{f}$ & $\%$ & $\%$ \\
\hline Perdarahan & 14 & 17.1 & 68 & 82.9 & 100 \\
Nyeri Pinggang & 19 & 23.2 & 63 & 76.8 & 100 \\
Nyeri Perut & 6 & 7.4 & 76 & 92.6 & 100 \\
Keputihan & 16 & 19.6 & 66 & 80.4 & 100 \\
Nyeri Kepala dan Kelemahan & 6 & 7.4 & 76 & 92.6 & 100 \\
Haid tidak teratur & 44 & 53.6 & 38 & 46.4 & 100 \\
Seksual & 5 & 6.1 & 77 & 93.9 & 100 \\
\hline
\end{tabular}

Berdasarkan tabel 2 di atas menunjukkan hasil bahwa kendala penggunaan $\mathrm{KB}$ IUD PP mayoritas adalah pada haid tidak teratur yaitu sejumlah 44 responden $(53.6 \%)$. Sedangkan untuk kendala seksual dan nyeri kepala, kelamahan merupakan kendala minoritas pada responden pengguna KB IUD PP yaitu sejumlah 5 responden (6.1\%). 


\section{Tingkat Kepuasan Pemasangan KB IUD Pasca Salin}

Tabel 3

Distribusi Frekuensi Kepuasan Pemasangan KB IUD Pasca Salin (N :82)

\begin{tabular}{|c|c|c|c|c|c|}
\hline \multirow{2}{*}{$\begin{array}{l}\text { Kepuasan Penggunaan } \\
\text { KB IUDPP }\end{array}$} & \multicolumn{2}{|c|}{ Puas } & \multicolumn{2}{|c|}{ Tidak puas } & \multirow{2}{*}{$\begin{array}{l}\text { TOTAL } \\
\%\end{array}$} \\
\hline & $\mathrm{f}$ & $\%$ & $\mathrm{f}$ & $\%$ & \\
\hline $\begin{array}{l}\text { Kemudahan dalam } \\
\text { pelayanan KB IUDPP }\end{array}$ & 75 & 91.4 & 7 & 8.6 & 100 \\
\hline $\begin{array}{l}\text { Penjelasan detail } \\
\text { tentang KB IUDPP }\end{array}$ & 66 & 80.4 & 16 & 19.6 & 100 \\
\hline $\begin{array}{l}\text { Penjelsan Proses } \\
\text { Pemasangan }\end{array}$ & 66 & 80.4 & 16 & 19.6 & 100 \\
\hline $\begin{array}{l}\text { Menandatangani } \\
\text { inform consent tanpa } \\
\text { paksaan }\end{array}$ & 82 & 100 & 0 & 0 & 100 \\
\hline $\begin{array}{l}\text { Penjelasan cara cek } \\
\text { String KBIUDPP }\end{array}$ & 66 & 80.4 & 16 & 19.6 & 100 \\
\hline Kondisi Instrumen & 80 & 97.5 & 2 & 2.5 & 100 \\
\hline $\begin{array}{l}\text { Proses pemasangan } \\
\text { secara aseptik }\end{array}$ & 75 & 91.4 & 7 & 8.6 & 100 \\
\hline $\begin{array}{l}\text { Merasa aman dan } \\
\text { nyaman selama } \\
\text { pemasangan }\end{array}$ & 65 & 79.2 & 17 & 20.8 & 100 \\
\hline $\begin{array}{l}\text { Dokter/Perawat/bidan } \\
\text { tanggap terhadap } \\
\text { keluhan seusai } \\
\text { pemasangan }\end{array}$ & 70 & 85.3 & 12 & 14.7 & 100 \\
\hline $\begin{array}{l}\text { Dokter/perawat /bidan } \\
\text { melakukan pengkajian } \\
\text { ulang /evaluasi } \\
\text { terhadap alat KB } \\
\text { IUDPP }\end{array}$ & 67 & 81.7 & 15 & 18.3 & 100 \\
\hline
\end{tabular}

Berdasarkan tabel 3 di atas menunjukkan hasil bahwa kepuasan pemasangan $\mathrm{KB}$ IUD PP mayoritas adalah pada menandatangai inform consent tanpa paksaan yaitu sejumlah 82 responden (100\%). Sedangkan mayoritas responden mearasa tdak puas pada aspek aman dan nyaman selama pemasangan responden pengguna KB IUD PP yaitu sejumlah 17 responden $(20.8 \%)$.

Hasil penelitian pada tabel 1 menunjukkan bahwa usia rerata responden adalah 33 tahun. Usia responden termuda yaitu 24 tahun dan yang paling tua yaitu 48 tahun. Usia reproduksi wanita berlangsung dari haid pertama hingga wanita menopause. Penelitian ini sejalan dengan penelitian yang dilakukan oleh Tessa Madden bahwa responden mayoritas pengguna IUDPP adalah wanita usia subur antar umur 20 s.d 48 tahun (Tessa Madden,2015) Hasil penelitian menyatakan bahwa penggunaan KB IUDPP lebih besar pada grand multipara daripada primipara. Penelitian ini sejalan dengan penelitian Rukiya Abdulwahab Mwinyi Ali (2012) yaitu pengguna KB IUD PP lebih banyak pada grand multipara $(74.8 .2 \%)$ daripada primipara $(25.2 \%)$

Hasil penelitian menunjukkan bahwa responden mengeluhkan penggunaan Kontrasepsi IUD PP memiliki kendala haid menjadi tidak teratur. Hal ini sejalan dnegan penelitian yang dilakukan oleh Bednarek PH, Jensen JT (2015) bahwa pasien mengalami menstruasi yang tidak teratur selama penggunaan IUDPP, bahkan $18 \%$ 
responden mengatakan bahwa tidak mengalami menstruasi dalam 1 tahun penggunaan IUD PP .

Penelitian menunjukkan bahwa responden memiliki keluhan keputihan setelah penggunaan KB IUDPP sejumlah 16\%. Hal ini sejalan dengan penelitian Anita Makin (2018) bahwa keputihan dan sakit perut adalah keluhan yang paling umum $(6,9 \%$ dan 4,4\%). Keluhan keputihan dan sakit perut bisa mengindikasikan infeksi ringan

Dalam penelitian ini didapatkan hasil bahwa responden mengalami puas terhadap inform consent yang diberikan tanpa paksakan. Proses penyampaian informed consent untuk penempatan IUD postpartum mengharuskan pasien memahami prosedur, alternatif, manfaat, dan risiko yang dijelaskan oleh dokter/perawat atau bidan. Idealnya, penjelasan ini harus dilakukan saat kunjungan prenatal. Hal ini dikarenakan terdapat waktu untuk diskusi, bertanya, dan pengambilan keputusan. Pseien dalam kondisi stabil dan tidak stres karena persalinan atau gejala lain. Ketika pasien sudah memasuki persalinan aktif, pasien dapat menegaskan kembali persetujuannya dan menandatangani formulir persetujuan. Namun, pasien dengan kunjungan prenatal minimal proses inform consent dapat dilakukan saat proses persalinan berlangsung. Pasien yang membutuhkan induksi atau augmentasi persalinan mungkin memiliki waktu untuk konseling yang memadai sedangkan pasien yang datang dengan kontraksi yang kuat atau persalinan yang tergesa-gesa mungkin tidak. Konseling kontrasepsi menggunakan pengambilan keputusan bersama secara signifikan meningkatkan kepuasan pasien dengan metode yang dipilih (Dehlendorf,2017)

Secara keseluruhan responden menyatakan kepuasan terhadap pemasangan KB IUD PP. Hal ini sejalan dengan penelitian Dhruvendra Pandey(2018) yaitu 63\% klien merasa puas mengutip bahwa IUD adalah alat kontrasepsi yang baik

\section{SIMPULAN DAN SARAN \\ Simpulan}

Kendala penggunaan KB IUD PP mayoritas adalah pada haid tidak teratur yaitu sejumlah 44 responden (53.6\%). Sedangkan untuk kendala seksual dan nyeri kepala, kelamahan merupakan kendala minoritas pada responden pengguna KB IUD PP yaitu sejumlah 5 responden (6.1\%). kepuasan pemasangan KB IUD PP mayoritas adalah pada menandatangai inform consent tanpa paksaan yaitu sejumlah 82 responden (100\%).

\section{Saran}

Kenyamanan pasien ditingkatkan selama pemasangan.

\section{DAFTAR PUSTAKA}

Anita Makin. (2018). FIGO postpartum intrauterine device initiative: Complication rates across six countries. Online Accessed : https://obgyn.onlinelibrary.wiley.com/doi/full/10.1002/ijgo.12600.

Bednarek, P.H, \& Jensen, J.T. (2015). Safety, efficacy and patient acceptability of thecontraceptive and non-contraceptive uses of the LNG-IUS. Int J WomensHealth.;1:45-58.

Brahmana, I. \& Prabowo, A. (2018). Adoption of Post-Abortion Contraception Program: Initial Effort by Trained Providers in Klaten, Central Java, Indonesia. Presented in Poster Presentation, ISQua 35, Malaysia. 
Brahmana, I. \& Prabowo, A. (2018). Championing the Integration of Post-Partum Contraception Program in Maternal and Child Health Services: Initial Effort by Trained Providers in Klaten, Central Java, Indonesia. Accepted Abstract as Poster Presentation in International Conference of Family Planning, Rwanda, Africa.

Dehlendorf, C., Grumbach, K., Schmittdiel, J.A., Steinauer, J. (2017). Shared decisionmaking in contraceptive counseling. Contraception;95:452-5.

Infodatin. (2014). Pusat Data dan Informasi Kementrian Kesehatan RI.

Rukiya Abdulwahab Mwinyi Ali. (2012). A Dissertation Submitted in Partial Fulfillment of the Requirements for the Degree of Master of Medicine in Obstetrics and Gynecology of the Muhimbili University of Health and Allied Science. Muhimbili University of Health and Allied Sciences

Tessa, Madden. (2015). Association of Age and Parity With Intrauterine Device Expulsion.

Online https://www.ncbi.nlm.nih.gov/pmc/articles/PMC4172535/\#!po=36.6667 